\title{
Africa Where Are You?
}

We all have self-centred views of the world: for some it ends with their own Main Street, and for some others at the national border of wherever they happen to live. The global people, of course, think they know it all, because they have seen every Sheraton hotel in the world.

Nonetheless, it seems to me that many Latin Americans have a particularly blank, not to say a distorted view of Africa.They seem to think that it still is the «dark continent» as the colonialists called it.It is even less well known here than in my native Europe. I am a stranger to Latin America, and I more often visit Africa where I also used to live for three years. In my viewAfrica is no longer «dark» (if ever it was) - only in our minds.

Taking darkness literally and by counting the light bulbs, Africa is and for some time to come will remainrelatively dark. The Economist reported in 2007 that with nearly 1 billion people, Africa accounts for over a sixth of the world's population, but generates only $4 \%$ of global electricity.

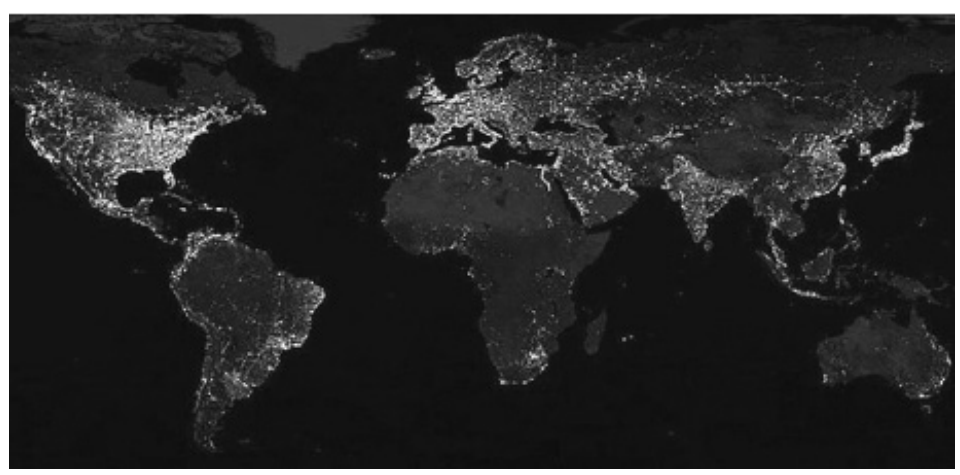

NASA satellite photo of Earth at night. Note the difference between Africa and South America, India, or the US.

This op-ed is not meant to sum up Africa in yet another series of clichés. I do not pretend to know it any better than 
I know the Americas. But by sharing some highlights and anecdotes I can perhaps convince a few readers to look further.

For instance, in the realm of communications we can see that the "dark» is quickly fading. A revolution is taking place which it is worth watching. To name just telephones as a means of ever-growing interaction, Africa sees a phenomenal expansion of cell phones (from 1\% in 2000 to $55 \%$ in 2012) - three times the world average.Similarly, broad band penetration is growing faster than anywhere else.

Those interested in music and other cultural achievements already know Africa for its achievements. The good news is that with better intellectual property protection African musicians can and do now produce in Africa.Also, with global art markets not only the famous TingaTinga paintings from Tanzania make their way to the artgalleries in Miami. Art collectors beware!

Development indicators are impressive: 20 countries enjoy an average growth rate of $5 \%$, rarely matched by Latin American countries.In the last four years, even though violent conflicts have affected 10 of the 49 African countries, overall poverty is receding just about everywhere else. In 9 major countries where average incomes had gone down $12 \%$ between 1998 and 2002,gross domestic product per person increased by a phenomenal 23\% between 2008 and 2012.And that is only a beginning: in the continent with even more commodities than in South America,half a dozen countries such as Ghana, Uganda, Tanzania and Somalia have in recent years started oil and natural gas extraction, in addition to still growing Nigeria, Angola, Libya, Algeria, Egypt, Sudan, Equatorial Guinea, Chad, Congo and Gabon. There is more, of course, and more than economic growth and a commodity boom. Unfortunately, good news is no news, so when Africa does reach international media headlines, we mostly see bad news.

Even so, I suggest these couple of pointers draw a rather different view of Africa than the stagnation, mass unemployment and recess we see in many European countries and elsewhere. But it really is when you combine the good news with African demographics that you can see the prospects for this continent:while roughly 1 billion people live in Africa today, there will be twice as many consumers by 2050 - a wild if long- 
term dream for global and local companies producing and selling consumer goods and services. Africans already spend more than Indians and Russians. A McKinsey market study puts investments in African retailing, private banking, and telecom and travel sectors until 2020 at \$400bn. In 2012 the US-based giant retailer Wal-Mart bought Massmart,a South African company, for $\$ 2.5$ bn and now plans to open 1250 additional stores all over Africa - even the rapid expansion of Chile's supermarket chain Cencosud in Colombia, Peru, Argentina and Brazil is no match here!The German retailer Spar, and household appliance producers like Mr Price and Truworths, are busily reinforcing their presence. With growing upstream linkages and credits for supermarket suppliers, this story goes far beyond cities and way into the rural areas.

Despite these bright prospects most Chileans seem to remain riveted to their traditional markets, universities and holiday destinations in North America and Europe. A few more courageous ones do look to Asia which moves faster than both. But who goes to Africa? I think the «first mover advantage» in Latin America goes to Petrobras which has crossed the Atlantic to start offshore oil-drilling in Nigeria, Angola and elsewhere, followed by the still state-owned Pemex from Mexico and Pluspetrol, anArgentinian family business. On a more general level, the Brazilian government encourages all moves to deepen relations with Africa, especially (but not only) with the Portuguesespeaking countries Angola, Cape Verde, and Mozambique.

What could Chilean companies and individuals do in Africa? I honestly cannot recommend making friends with the dictator in the only Spanish-speaking country in Africa, Equatorial Guinea. But on my homebound flight to Paris I sat next to a young Argentinian geologist on his way to a new venture in Abidjan. Did you know that Santiago is closer to this dancing city than to Miami? There you can find not only offshore oil exploration, it is also a vibrant hub for new African music and other arts, and genuine traditional handicrafts, like much of West Africa. Did you know the cast bronze (in French, cireperdue) technique of Igboland (Igbo-Ukwu) in Nigeria dates back to the 9th century? In the same region I love watching preparations for the traditional staple food called «Fufu» (in French, foufou): three women pounding in 
regular turns a manioc paste which then comes with fish or meat in a finger-licking chilli sauce.

Let's cross the continent and go to the Eastern shores where traders from Osman established in Zanzibar even before they went all the way to Bali. Enjoy the safari and trekking to Kilimanjaro before you travel to Madagascar and other Indian Ocean islands with beauties, traditional two story brick houses and other crafts. Actually, the highland population of this island larger than California came all the way from Polynesia:the first South-South cultural connect, on the same frail sailing boats and rafts which also landed in the Easter Islands, five hundred years before the first Chilean mutton farmers went there!

For business, you can also trySouth Africa and Nigeria, the economic giants of the continent. Your business proposals will best team up with local entrepreneurs -with dances and theatre visits included, not to forget the fabulous national parks in the whole South African region.

While the origin of humanity is in Sub-Saharan Africa, more precisely in Kenya and Ethiopia, it is Egypt which of all African countries has contributed most to the Greek and Roman civilisation and which until today offers oil and beaches and food and Islamic high culture dating back to the Middle Ages.

What then could Chile on the other side of the South Pacific contribute, and where could not only its tourists but also its economy benefit from Africa?Let me suggest just one field in concluding this quick overview - without any pretence to increase shareholder value. Chile is one leading copper producer, and it has a longstanding experience on how to lead part of the proceeds from the red metal into its own economic growth. The debate on how much more could be obtained is open. Fact is, Zambia and Zimbabwe got and get less than half the royalties for the same quantities of the mineral ore. How about offering Chile's regulating and negotiating experience it has made over many years with copper multinationals?

For me, living at the end of the world like Chileans do is no reason to see Africa as one poor country with civil wars, nudes and safaris. Look again!

Christian Häberli

PhD (Law), Senior Research Fellow, World Trade Institute (WTI), Bern University (Switzerland) 